\title{
The Effect of Different Doses of Blue Light on the Biometric Traits and Photosynthesis of Dill Plants
}

\author{
Barbara FRĄSZCZAK
}

\author{
Poznań University of Life Sciences, Faculty of Horticulture and Landscape Architecture, Department of Vegetable Crops, Dąbrowskiego 159, 60-594Poznań, \\ Poland;barbaraf@up.poznan.pl
}

\begin{abstract}
The supplementation of blue light to red light enhanced plant growth compared with the use of red alone. The aim of the study was to determine the effect of different doses of blue light on the biometric traits and photosynthesis of dill plants. The plants were grown in pots in a growth chamber. They were grown in red light $\left(100 \mu \mathrm{mol} \mathrm{m}^{-2} \mathrm{~s}^{-1}\right)$ and blue light (from 10 to 50 $\mu \mathrm{mol} \mathrm{m} \mathrm{m}^{-2}$ ) in five combinations. Light emitting diode modules were the source of light. The plants were evaluated every 7 days during vegetation, for the first time - seven days after germination and later on the $14^{\text {th }}, 21^{\text {st }}$ and $28^{\text {th }}$ day after germination. The share of blue light in the spectrum significantly influenced the biometric traits of the dill plants. It significantly inhibited the elongation growth of the plants and negatively affected the increase in fresh weight. A small dose of blue light (20\%) had positive effect on the plants' area. The research did not reveal a simple relationship between the amount of blue light and dry weight yield. The value of physiological indexes depended both on the combination and measurement time. The plants from the combination with $30 \%$ blue light were characterised by the greatest photosynthesis intensity. An effective share of blue light in the spectrum may range from 10 to $30 \%$ in relation to red light and depends on the plant's development phase and on the result we want to achieve in the cultivation of plants.
\end{abstract}

Keywords: Anethum graveolens L., light emitting diodes (LEDs), light quality, photomorphogenesis

\section{Introduction}

Spice plants grown and sold in containers tend to have excessively elongated hypocotyl at the initial period of cultivation due to their high density and usually insufficient amount of light. This situation results in worse quality of plants for sale (Callan et al., 2007). Dill is characterised by very high elongation of plants (Frązzzak et al., 2008). Decreasing light levels result in decreased numbers of dill leaves, lesser leaf area and plant height (Hälvä $e t$ al, 1992a).Plant growth and morphogenesis are strongly influenced by the light spectrum and both yield and crop quality could be improved by controlling light quality (Whitelam and Halliday, 2007). Hanyu and Shoji (2002) suggested that yield and crop quality could be improved by controlling light quality. For example, blue light suppresses hypocotyl elongation and induces cotyledon expansion, whereas red light induces hypocotyl elongation and cotyledon expansion in Arabidopsis seedlings (Johkan et al, 2010). According to Hälvä et al (1992b), red light increased dill plant growth and induced the elongation of internodes. By contrast, blue light-treated plants had shorter internodes and produced relatively high herb yields.
The combination of red and blue light is the most photosynthetically effective at the leaflevel. The absence of one of the two light wavebands creates photosynthetic inefficiencies (Hogewoning et al., 2010). The percentage of absorption of blue or red light by plant leaves is about $90 \%$ (Terashima $e t a l ., 2009)$. The combination of red and blue light has proved to be an effective source of light for producing some vegetables (Hirai et al., 2006; Fan et al. 2013; Sabzalian et al. 2014). However, the optimal amount of blue light in the spectrum is still under discussion (Massa et al., 2008; Hogewoning et al., 2010). The optimal proportion of blue light in red-blue light is expected to range from 7 to 20\% (Ptushenko et al, 2015). Many studies have demonstrated different combinations of red and blue light to be effective for the growth of some plants. 1:1 ratio was found to be more effective for the growth of cherry tomato plants (Fan et al., 2013), 0.9:0.1 would be an acceptable level for the growth of lettuce, spinach and radish (Yorio et al, 2001; Wojciechowska et al, 2015). The abovementioned and other publications suggest that crops react to blue light in different ways (Massa et al.2008) and their reaction depends on the species and the photosynthetic photon flux density (PPFD) (Hirai et al., 2006; Fan etal.,2013). 
Based on the data available to date, one can raise two questions. Firstly, how much blue light should be added to ensure normal growth and development of dill plants? Secondly, does the amount of blue light in the spectrum also depend on the amount of red light or should it be constant regardless of the quantity of red light? Therefore, in this study we tested how a constant amount of red light combined with blue light at different ratios (from 10 to $50 \%$ ) affected the growth of dill.

\section{Materials and Methods}

\section{Plant material and growth conditions}

The experiments were carried out in 2014 in growth chambers of the Marcelin experimental station of the Poznan University of Life Sciences, Poland. Dill (Anethum graveolens L., cv. 'Ambrozja') was used as a plant material. The 'Ambrozja' cultivar was chosen after another research conducted by the author of this study (Fraszczak, 2009). It is characterised by the highest growth dynamics in comparison with other dill cultivars. The plants were grown in $280 \mathrm{~cm}^{3}$ pots, in a cultivation area of $49 \mathrm{~cm}^{2}$, filled with peat substrate for vegetable transplanting production (KlassmannDeilman, Germany). The number of plants grown in a pot was identical and amounted to 40 ( \pm 5 plants). A 16 -h photoperiod and a day/night temperature of $23 / 18{ }^{\circ} \mathrm{C}$ were maintained. The relative air humidity was $65-70 \%$.

After germination the dill plants were cultivated for 28 days (four weeks). Red and blue diode modules (type SMD, Seoul Semiconductor, South Korea) were the source of light (Fig. 1). The red light photosynthetic photon flux density (PPFD) was about $100 \mu \mathrm{mol} \mathrm{m} \mathrm{s}^{-1}$. The blue light PPFD varied $(10-50 \mu \mathrm{mol}$ $\mathrm{m}^{-2} \mathrm{~s}^{-1}$ ) depending on the combination (Table 1). The PPFD was measured with a quantum sensor (PAR-10; Sanopan, Białystok, Poland). The spectral distribution of light treatments was measured with a spectroradiometer BLACK-Comet CXR, 280$900 \mathrm{~nm}$ (UV-VIS by StellarNet Inc., Tampa, USA). The measurements were made $15 \mathrm{~cm}$ under the lamps, more or less at the height of the tops of the plants.

\section{Growth and morphology analysis}

The plants were evaluated every 7 days during vegetation, for the first time - seven days after germination and later on the $14^{\text {th }}$, $21^{\text {st }}$ and $28^{\text {th }}$ day after germination. Harvesting involved handcutting of the plants close to the surface of the substrate. After harvest, the weight of the fresh matter of the plants from eight pots was determined. In addition, measurements of the plants height, hypocotyl length and leaf area were taken (ten plants per pot, eight pots per treatment). A scanner (Mustek 1200 UB) and the Skwer program (IksmodaR, Poland) were used to calculate the area of leaves. Dry mass was determined by drying the material to constant weight at $105{ }^{\circ} \mathrm{C}$ for $24 \mathrm{~h}$ (PN-90/A-75101/03 1990). Photosynthesis was measured using a gas exchange measurement system (LCpro+, ADC BioScientific). Gas exchange was measured using a custom-made leaf chamber $-6.25 \mathrm{~cm}^{2}$. After steady-state rates of A had been recorded (approx. $1 \mathrm{~h}$ ), leaves were removed from the chamber and the leaf area was measured. Photosynthesis was measured under the conditions in which plants were grown, in the fourth week of cultivation.

\section{Physiological indices}

The relative growth rate (RGR), net assimilation rate (NAR), specific leaf area (SLA), and leaf area index (LAI) were calculated as described by Hunt (1982). The RGR was calculated according to the following formula: $R G R=\left(\ln W_{2^{-}}\right.$ $\left.\ln \mathrm{W}_{1}\right)\left(\mathrm{t}_{2}-\mathrm{t}_{1}\right)$, where: $\mathrm{W}_{2}$ and $\mathrm{W}_{1}$ are plant dry mass $(\mathrm{g})$, at times $\mathrm{t}_{2}$ and $t_{1}$, respectively. The NAR is the increment of biomass per unit of time and per unit of any measure of magnitude of the assimilation organs: $\mathrm{NAR}=\mathrm{dW} /(\mathrm{A} \cdot \mathrm{dt})$, where: $\mathrm{A}$ - area of assimilation organs $\left(\mathrm{dm}^{2}\right), \mathrm{dW}$ - dry mass increment $(\mathrm{g})$, dt - time of cultivation (day).

The SLA is defined as the ratio between the leaf area and the dry mass of leaves. SLA $=\mathrm{L}_{\mathrm{A}} / \mathrm{L}_{\mathrm{W}}$, where: $\mathrm{L}_{\mathrm{A}}$ - leaf area $\left(\mathrm{dm}^{2}\right), \mathrm{L}_{\mathbb{W}}$ dry mass of leaves $(\mathrm{g})$. The LAI refers to the area of the leaf surface in relation to the pot area taken up by all plants. It was calculated according to the following formula: $\mathrm{LAI}=\mathrm{A} / \mathrm{P}$, where: A - plant assimilation area $\left(\mathrm{dm}^{2}\right), \mathrm{P}$ - pot area $\left(\mathrm{dm}^{2}\right)$.

\section{Statistical analysis}

The experiment was performed in eight replicates with three pots being treated as one replicate. The investigations were

\begin{tabular}{|c|c|c|c|}
\hline \multirow[t]{2}{*}{ Treatment } & $\begin{array}{l}\text { Red light } \\
(640 \mathrm{~nm})\end{array}$ & $\begin{array}{l}\text { Blue light } \\
(455 \mathrm{~nm})\end{array}$ & $\begin{array}{c}\text { Total } \\
\left(\text { PPFD }^{*}\right)\end{array}$ \\
\hline & \multicolumn{3}{|c|}{$\mu \mathrm{mol} \mathrm{m} \mathrm{m}^{-2} \mathrm{~s}^{-1}$} \\
\hline $10 \% \mathrm{BL}^{*}$ & 107.8 & 9.82 & 117.6 \\
\hline $20 \% \mathrm{BL}$ & 107.8 & 23.2 & 131.0 \\
\hline $30 \% \mathrm{BL}$ & 107.8 & 33.6 & 141.4 \\
\hline $40 \% \mathrm{BL}$ & 107.8 & 39.7 & 147.5 \\
\hline $50 \% \mathrm{BL}$ & 107.8 & 52.3 & 160.1 \\
\hline
\end{tabular}

${ }^{*}$ PPFD - photosynthetic photon flux density, BL - blue light

\section{B}

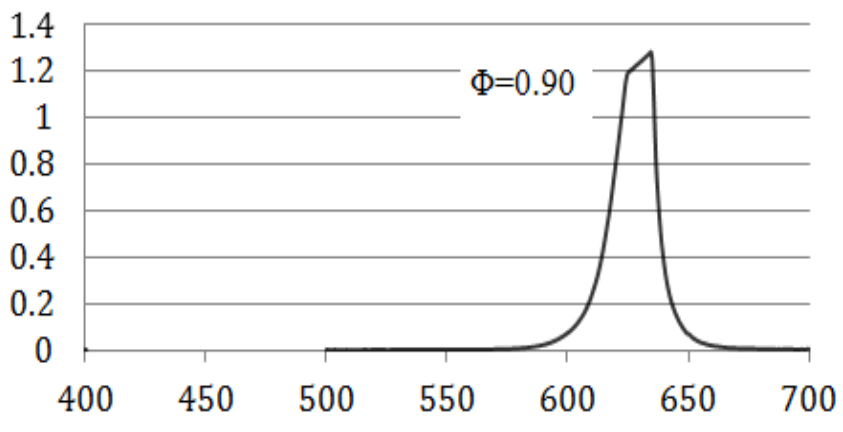

Fig. 1. The spectral photon distribution of LED light sources: blue light (A) and red light (B) 
36

conducted in two consecutive cycles. The results show the mean values of the two series. Measurements of morphology, dry matter, photosynthetic rate and physiological indices were analysed statistically with one-way analysis of variance (ANOVA). Differences between the means were estimated with the Newman-Keuls test at a significance level of $\alpha=0.05$. All statistical analyses were carried out with the Statistica program (StatSoft, Poland).

\section{Results}

\section{Morphologicalparameters}

The amount of blue light in the spectrum had significant influence on the hypocotyl length (Table 2). During the first two weeks of growth the shortest hypocotyl was observed in the plants growing under $50 \%$ blue light. In the consecutive weeks the hypocotyl was also the shortest in the plants growing under $40 \%$ blue light. Blue light had similar effect on the height of the plants. During the whole growth period the tallest plants were observed with the smallest amount of blue light (10\%). In the consecutive weeks of cultivation, when the share of blue light was as low as 20$30 \%$, it significantly inhibited the elongation growth of the plants. During the first three weeks of cultivation the plants growing under $20 \%$ blue light were characterised by greater area. During the last week of cultivation the area of the plants in all combinations was similar, except the plants growing under 50\% blue light.

\section{Drymass content}

It is difficult to prove the direct dependence between the content of dry weight in the herbage and the share of blue light in the spectrum (Table 3) upon analysis of the research findings.

Table 2. The effect of different doses of blue light on the morphological parameters of dill

\begin{tabular}{|c|c|c|c|c|}
\hline Treatment & $\begin{array}{l}\text { Hypocotyl } \\
\text { length }(\mathrm{cm})\end{array}$ & $\begin{array}{l}\text { Height } \\
(\mathrm{cm})\end{array}$ & $\begin{array}{c}\text { Fresh mass } \\
\left(\mathrm{g} \mathrm{pot}^{-1}\right)\end{array}$ & $\begin{array}{c}\text { Plant area } \\
\left(\mathrm{dm}^{2} \text { pot }^{-1}\right)\end{array}$ \\
\hline \multicolumn{5}{|c|}{$7^{\text {th }}$ day } \\
\hline $10 \% \mathrm{BL}$ & $3.0 \mathrm{a}^{*}$ & $5.7 \mathrm{a}$ & $1.58 \mathrm{ab}$ & $0.46 \mathrm{~b}$ \\
\hline $20 \% \mathrm{BL}$ & $3.1 \mathrm{a}$ & $5.3 \mathrm{a}$ & $1.76 \mathrm{a}$ & $0.63 \mathrm{a}$ \\
\hline $30 \% \mathrm{BL}$ & $3.2 \mathrm{a}$ & $5.7 \mathrm{a}$ & $1.26 \mathrm{bc}$ & $0.43 \mathrm{~b}$ \\
\hline $40 \% \mathrm{BL}$ & $2.9 \mathrm{a}$ & $5.4 \mathrm{a}$ & $1.46 \mathrm{~b}$ & $0.40 \mathrm{~b}$ \\
\hline $50 \% \mathrm{BL}$ & $2.4 \mathrm{~b}$ & $4.5 \mathrm{~b}$ & $1.50 \mathrm{~b}$ & $0.49 \mathrm{~b}$ \\
\hline \multicolumn{5}{|c|}{$14^{\text {th }}$ day } \\
\hline $10 \% \mathrm{BL}$ & $3.7 \mathrm{a}$ & $9.4 \mathrm{a}$ & $3.96 \mathrm{~b}$ & $0.61 \mathrm{ab}$ \\
\hline $20 \% \mathrm{BL}$ & $3.4 \mathrm{~b}$ & $7.6 \mathrm{~b}$ & $5.52 \mathrm{a}$ & $0.91 \mathrm{a}$ \\
\hline $30 \% \mathrm{BL}$ & $3.4 \mathrm{~b}$ & $6.6 c$ & $2.96 \mathrm{c}$ & $0.52 \mathrm{~b}$ \\
\hline $40 \% \mathrm{BL}$ & $3.1 \mathrm{~b}$ & $5.9 \mathrm{~d}$ & $3.04 \mathrm{c}$ & $0.53 \mathrm{~b}$ \\
\hline $50 \% \mathrm{BL}$ & $2.4 \mathrm{c}$ & $5.8 \mathrm{~d}$ & $2.96 \mathrm{c}$ & $0.59 \mathrm{ab}$ \\
\hline \multicolumn{5}{|c|}{$21^{\text {st }}$ day } \\
\hline $10 \% \mathrm{BL}$ & $3.8 \mathrm{a}$ & $9.6 \mathrm{a}$ & $5.32 \mathrm{ab}$ & $0.82 \mathrm{~b}$ \\
\hline $20 \% \mathrm{BL}$ & $3.7 \mathrm{a}$ & $8.9 \mathrm{ab}$ & $6.80 \mathrm{a}$ & $1.10 \mathrm{a}$ \\
\hline $30 \% \mathrm{BL}$ & $3.8 \mathrm{a}$ & $6.8 c$ & $3.28 \mathrm{~b}$ & $0.55 \mathrm{c}$ \\
\hline $40 \% \mathrm{BL}$ & $3.1 \mathrm{~b}$ & $8.5 \mathrm{~b}$ & $3.98 \mathrm{~b}$ & $0.85 \mathrm{~b}$ \\
\hline $50 \% \mathrm{BL}$ & $2.8 \mathrm{~b}$ & $8.4 \mathrm{~b}$ & $5.50 \mathrm{ab}$ & $0.91 \mathrm{~b}$ \\
\hline \multicolumn{5}{|c|}{$28^{\text {th }}$ day } \\
\hline $10 \% \mathrm{BL}$ & $3.9 \mathrm{a}$ & $11.2 \mathrm{a}$ & $8.72 \mathrm{ab}$ & $1.46 \mathrm{a}$ \\
\hline $20 \% \mathrm{BL}$ & $4.0 \mathrm{a}$ & $9.0 \mathrm{~b}$ & $9.42 \mathrm{a}$ & $1.56 \mathrm{a}$ \\
\hline $30 \% \mathrm{BL}$ & $3.9 \mathrm{a}$ & $8.8 \mathrm{~b}$ & $7.24 \mathrm{~b}$ & $1.54 \mathrm{a}$ \\
\hline $40 \% \mathrm{BL}$ & $3.7 \mathrm{ab}$ & $8.8 \mathrm{~b}$ & $7.60 \mathrm{~b}$ & $1.34 \mathrm{ab}$ \\
\hline $50 \% \mathrm{BL}$ & $3.4 \mathrm{~b}$ & $8.7 \mathrm{~b}$ & $7.04 \mathrm{~b}$ & $1.10 \mathrm{~b}$ \\
\hline
\end{tabular}

${ }^{*}$ Values followed by the same letters for individual dates do not differ significantly at $\alpha=0.05$,

BL-blue light, the percentage relative to $100 \mu \mathrm{mol} \mathrm{m} \mathrm{m}^{-2}$ red light, see Table 1.
During the whole vegetation period the dry weight yield was significantly lower in the combination with $30 \%$ blue light. On the other hand, the highest dry weight yield in the last week of measurements was observed in the combination with $40 \%$ blue light.

\section{Netphotosyntheticrate}

The highest intensity of photosynthesis was observed in the plants with smaller shares of blue light (10-30\%) (Fig. 2). The lowest intensity of photosynthesis was observed in the plants from the combination with $40 \% \mathrm{BL}$.

\section{Physiological indices}

Both the relative growth rate (RGR) and net assimilation rate (NAR) values varied depending on the measurement time and combination (Fig. 3).

At the initial growth period the greatest values of both indices were observed for the plants grown under 20\% BL. However, at later periods both the RGR and NAR values were significantly smaller in this combination. The combination $50 \% \mathrm{BL}$ was characterised by very high variability of these indices, depending on the measurement time. During the whole growth period there was a great value of the specific leaf area (SLA) in the combination grown under $30 \% \mathrm{BL}$. The combination was also characterised by a significantly smaller LAI value during the first three measurements. The greatest LAI value was observed in the combination $20 \%$ BL. By contrast, this combination was characterised by a significantly smaller SLA value than in the other combinations.

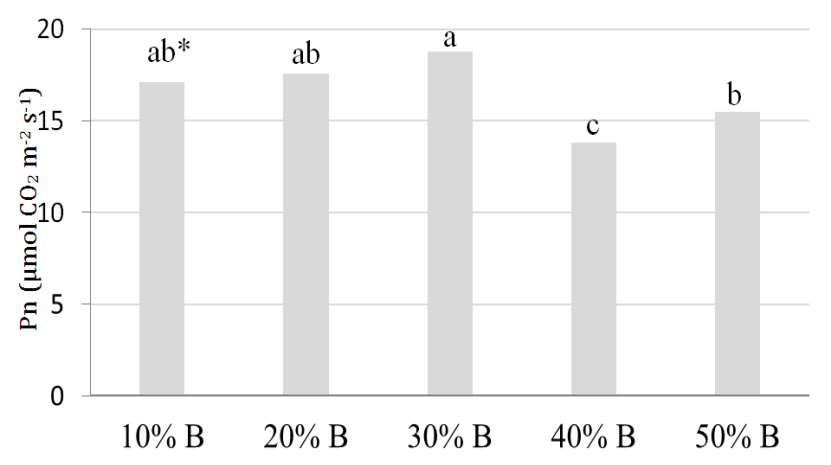

Fig. 2. The effect of different doses of blue light on the net photosynthetic rate $(\mathrm{Pn}) ;{ }^{*}$ values followed by the same letters for individual days do not differ significantly at $\alpha=0.05$, Bblue light, the percentage relative to $100 \mu \mathrm{mol} \mathrm{m} \mathrm{m}^{-2}$ red light, see Table 1 .

Table 3. The effect of different doses of blue light on the content of dry mass in dill herbage

\begin{tabular}{|c|c|c|c|c|c|c|c|c|}
\hline \multirow{3}{*}{$\begin{array}{l}\text { Treat- } \\
\text { ment }\end{array}$} & \multicolumn{8}{|c|}{ Drymass } \\
\hline & \multicolumn{2}{|c|}{$7^{\text {h day }}$ day } & \multicolumn{2}{|c|}{$14^{\text {th }}$ day } & \multicolumn{2}{|c|}{$21^{\star}$ day } & \multicolumn{2}{|c|}{$28^{\text {h day }}$} \\
\hline & (gpot') & (\%) & $\left(\right.$ gpot $\left.^{1}\right)$ & (\%) & $\left(\right.$ gpot $\left.^{1}\right)$ & (\%) & $\left(\mathrm{gpot}^{1}\right)$ & (\%) \\
\hline $10 \% \mathrm{BL}$ & $0.11 \mathrm{a}^{*}$ & 6.85 & $0.27 \mathrm{~b}$ & 6.85 & $0.45 \mathrm{~b}$ & 8.40 & $1.01 \mathrm{~b}$ & 11.59 \\
\hline $20 \% \mathrm{BL}$ & $0.13 a$ & 733 & $0.43 a$ & 7.80 & $0.84 \mathrm{a}$ & 1240 & $0.95 \mathrm{~b}$ & 1250 \\
\hline $30 \% \mathrm{BL}$ & $0.07 \mathrm{~b}$ & 5.95 & $0.17 \mathrm{c}$ & 5.85 & $0.36 \mathrm{~b}$ & 10.95 & $0.49 \mathrm{c}$ & 6.80 \\
\hline $40 \% \mathrm{BL}$ & $0.11 \mathrm{a}$ & 7.26 & $0.21 b c$ & 6.87 & $0.46 \mathrm{~b}$ & 11.80 & $1.43 \mathrm{a}$ & 15.30 \\
\hline $50 \% \mathrm{BL}$ & $0.13 a$ & 8.61 & $0.20 \mathrm{bc}$ & 6.80 & $0.73 a$ & 1335 & $0.74 \mathrm{bc}$ & 10.50 \\
\hline
\end{tabular}

*values followed by the same letters for individual days do not differ significantly at $\alpha=0.05$, ; BL - blue light, the percentage relative to $100 \mu \mathrm{mol}$ $\mathrm{m}^{-2} \mathrm{~s}^{-1}$ red light, see Table 1 . 

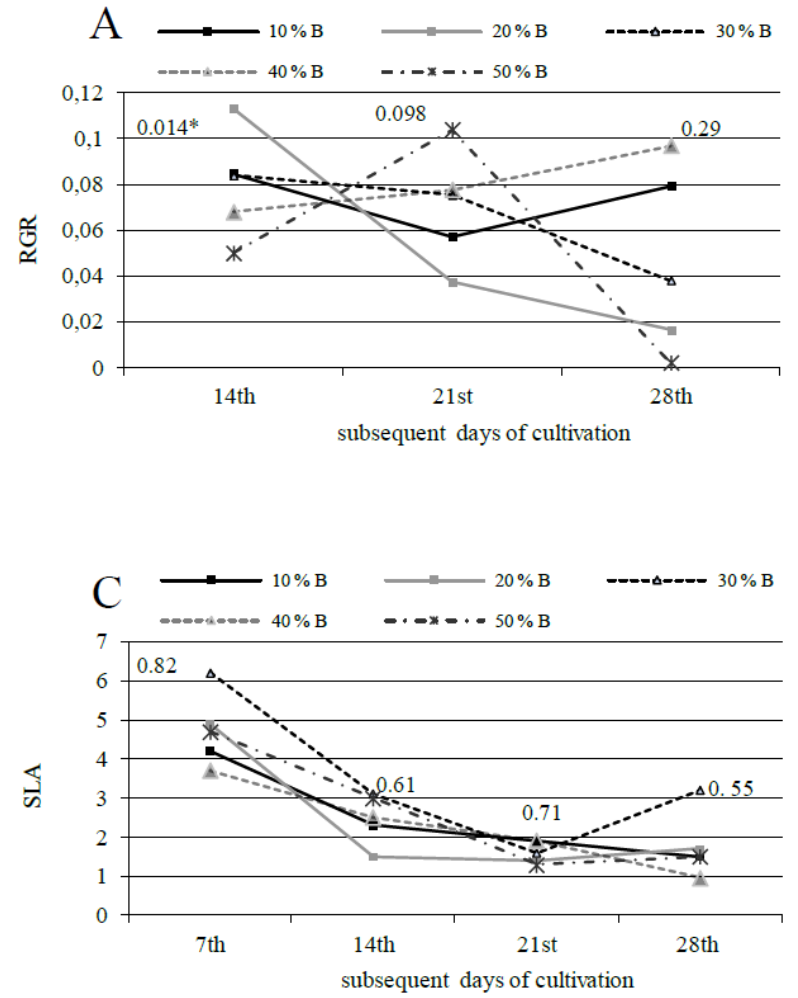
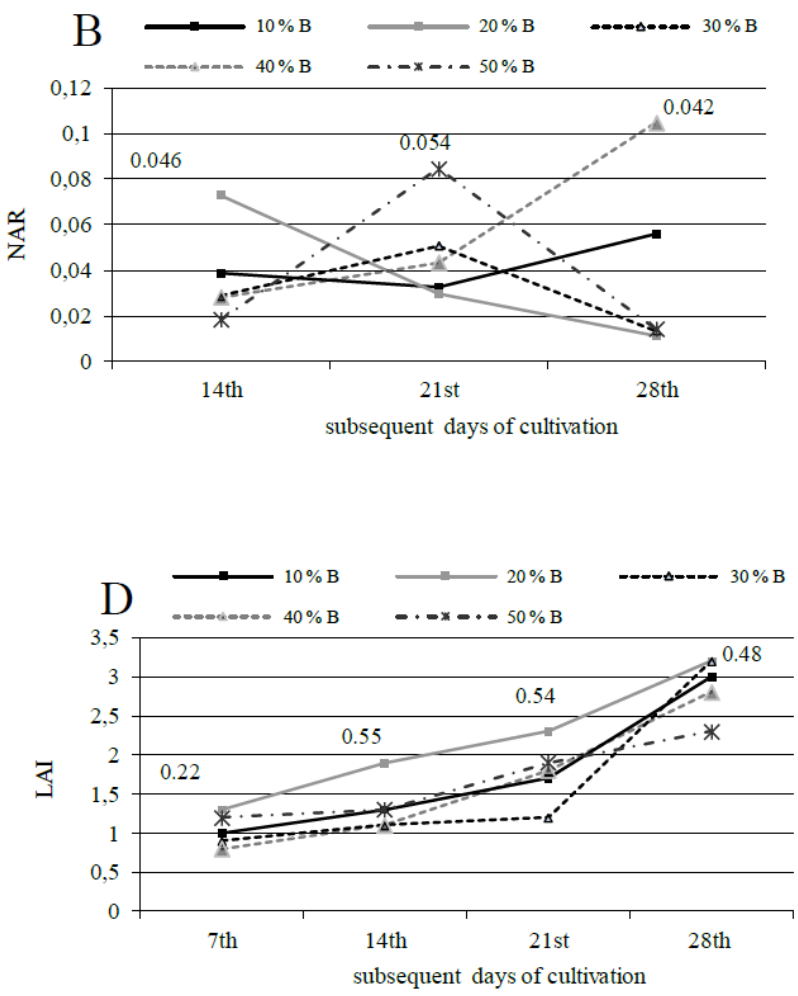

Fig. 3. The effect of different doses of blue light on A: relative growth rate - RGR $\left(\mathrm{g} \mathrm{g}^{-1} \mathrm{~d}^{-1}\right)$. B: net assimilation rate - NAR (g $\left.\mathrm{dm}^{-2} \mathrm{~d}^{-1}\right)$. C: specific leaf area - SLA $\left(\mathrm{dm}^{2} \mathrm{~g}^{-1}\right)$. D: leaf area index LAI $\left(\mathrm{dm}^{2} \mathrm{dm}^{-2}\right) ;{ }^{*}$ LSD - least significant differences, n.s. - not significant at $\alpha=0.05$, B-blue light, the percentage relative to $100 \mu \mathrm{mol} \mathrm{m} \mathrm{m}^{-2} \mathrm{~s}^{-1}$ red light, see Table 1 .

\section{Discussion}

\section{Morphologicalparameters}

Blue light is known to play the main role in photomorhogenesis - therefore, it is necessary for the growth and development of higher plants (Terfa et al., 2012; Woźny 2011). In this study blue light significantly affected the length of hypocotyl and the height of plants. The hypocotyl was the shortest in the combination grown under 50\% BL. Kwack et al. (2015) also found that blue light suppressed hypocotyl elongation in several vegetable sprouts. However, the response of stem elongation under blue or red light is apparently dependent on plant species (Hirai et al., 2006). Eggplants grown under blue light were characterised by much longer stems than the plants grown under other colours of light. Lettuce exhibited a completely opposite reaction. Plants' sensitivity to blue light and its influence on growth inhibition could be an individual quality of each species.

It is noteworthy that especially at the initial period of vegetation only the greatest dose of blue light (50\%) significantly influenced the inhibition of hypocotyl elongation. It is not only the existence of blue light in the spectrum but also the amount of blue light that matters. In the study by Ouzounis et al. (2014) an increased blue light ratio resulted in lower heights of roses and chrysanthemums. Also, in the study by Samuoliene et al. (2011) the hypocotyl was much shorter when plants were grown under red light with $10 \%$ blue light than in the combination with 5\% blue light.
At a later period of dill growth blue light did not have such strong influence on the hypocotyl elongation, because the plants' growth was much less intensive.

It was observed other dependences about the height of plants. At the initial period only $50 \%$ blue light inhibited the hypocotyl elongation. At later growth periods the hypocotyl elongation was also inhibited by $20-50 \%$ blue light. This situation may have been caused by more intensive growth of dill during that period and the plants' greater sensitivity to blue light. Fan et al. (2013) observed that the height of young tomato plants decreased as light intensity increased; a similar dependence was observed in this study.

The study proved a noticeable dependence between the share of blue light in the spectrum and the fresh weight of dill. The greatest amount of fresh weight was produced under 20\% $\mathrm{BL}$ and it did not differ significantly from 10\% BL (except the second measurement). Thus, when there was more than $20 \%$ of blue light in the spectrum, the growth of fresh weight of dill was inhibited. Ouzounis et al. (2015) revealed that the total fresh weight was not affected by additional blue light. Blue LEDs in combination with high light intensities are more efficient for biomass production in plants than red light (Muneer $e t$ al., 2014). In the study by Johkan et al. (2010) fresh weight was higher in lettuce plants treated with blue light after 45 days from sowing. But after 17 days from sowing there was higher fresh weight in plants treated with red light than in those treated with blue light. Red light may have caused a greater increase in biomass production at the initial period of growth than blue light. 
38

In general, blue light is thought to stimulate the growth of leaf area in plants (Johkan et al., 2010; Samuolienè et al., 2014). In this study at the initial period of measurements the greatest area and LAI were observed in the plants treated with $20 \% \mathrm{BL}$. Only the fourth measurement did not show differences in the plants' area or LAI under 10-40\% blue light. Hogewoning et al. (2010) also reported that in cucumber plants grown under HPS $(5 \% \mathrm{~B})$ the area was twice as large as in plants grown under fluorescent tubes with $23 \%$ B proportion. Terfa et al. (2013) also observed in their study that the area of rose leaves grown under white light with $20 \% \mathrm{BL}$ was much smaller than the area of rose leaves grown under $5 \% \mathrm{BL}$. There were similar findings in the study by Ouzounis et al. (2014), where the largest leaf area was observed in the rose plants in the combinations $20 \% \mathrm{~B} / 80 \% \mathrm{R}$ and $100 \% \mathrm{R}$, as compared with the combination $40 \% \mathrm{~B} / 60 \% \mathrm{R}$. Dougher and Bugbee (2001) defined long-term B light doseresponse curves for leaf area in soybean and lettuce. They showed that this parameter in soybean decreased with increment of the $B$ light proportion while the leaf area in lettuce increased with an increasing $B$ light fraction. In their experiment with soybean, they showed a $23 \%$ decrease in the leaf area when the B light fraction increased from $6 \%$ to $26 \%$. This was associated with a $15 \%$ decrease in the cell area (expansion) and $11 \%$ decrease in the cell number. According to these authors, the much lower average leaf area with increasing blue light fraction may be associated with a B light-mediated inhibition of cell expansion (Dougher and Bugbee, 2004).

\section{Net photosynthetic rate and dry weight}

According to literature data, plants can have a full life cycle only under red light, but the addition of blue light increases photosynthetic production in some plants (Lee et al., 2007; Wang et al. 2015). It is so because cryptochromes (CRYs) and phototropins are specifically sensitive to blue light and phytochromes are specifically sensitive to red light (Whitelam and Halliday, 2007). The greatest $\mathrm{Pn}$ value was observed in 30\% BL, which did not differ significantly from $10 \%$ and $20 \%$ BL. On the other hand, the lowest intensity of photosynthesis was observed in the plants grown under $40 \% \mathrm{BL}$. Thus, in this study the intensity of photosynthesis increased along with increasing $\mathrm{BL}$ only to a level of $30 \mu \mathrm{mol} \mathrm{m}^{-2} \mathrm{~s}^{-1} \mathrm{BL}$. The plants grown under $30 \% \mathrm{BL}$ were also characterised by the lowest yield of dry weight. The study by Liu et al. (2011) proved that the leaf thickness, the length of palisade tissue cells and the number of stomata in the epidermis of the leaves of cherry tomato seedlings increased significantly under the spectra containing blue light, as compared with the plants grown under other light treatments. According to Sun (2008), the abovementioned factors greatly influence photosynthesis in the leaves. However, it is intriguing that the intensity of photosynthesis decreased in $40 \%$ and $50 \% \mathrm{BL}$. In the study on Westar plantlets conducted by Li et al. (2013) the best photosynthetic parameters were observed in the combination $\mathrm{B}: \mathrm{R}=3: 1$, where the share of blue light was much greater than the share of red light. On the other hand, Hogewoning et al. (2010) observed in their study that the photosynthetic capacity $\left(\mathrm{A}_{\max }\right)$ increased with increasing blue light percentage during growth measured up from $7 \%$ to $50 \%$ blue light (the remaining percentage was red light). According to Wang et al. (2015), blue light optimised photosynthetic performance by improving the photosynthetic rate under low irradiance.
Greater photosynthetic intensity is usually reflected by an increase in the dry weight in herbage (Darko et al., 2014). When plants are grown in a mixture of red and blue light, the yield of dry weight is also greater than when plants are grown in red light only (Wang et al., 2009). On the other hand, according to Ouzounis et al. (2015) lettuce grown under blue LED lighting did not enhance FW and DW, but rather partitioned assimilates for other processes. In our study the smallest content of dry weight was observed in the combination $30 \% \mathrm{BL}$, where the photosynthetic intensity was the greatest. According to Yorio $e t$ al. (2001), a possible explanation for the discrepancy between Pn and dry weight accumulation could lie in the single point $\mathrm{Pn}$ measurement in our study.

\section{Physiological indices}

The diversified share of blue light had significant influence on assimilative indices. High SLA values were observed in the plants from the $30 \% \mathrm{BL}$ combination. It was correlated with the greatest Pn value in this combination. Sirtautas et al. (2014) conducted a study on lettuce, whereas Samuolienè et al. (2010) experimented on strawberries and they proved that the addition of blue light in the spectrum had positive effect on the SLA value. In the studies of Johkan et al. (2010) the SLA in lettuce under FL and red light was higher than under blue-containing LED lights. There was a 54\% decrease in the SLA between 0 and 2\% blue light.

The growth of plants is the result of interaction between environmental factors and biomass allocation parameters determining the potential RGR (Galmés et al., 2005). The RGR was correlated with its physiological (NAR) component. However, studies have not proved a simple dependence between the amount of blue light and the RGR and NAR values. In a study on baby leaf lettuce different supplemental blue light wavelengths had different effects on the growth rate: $455 \mathrm{~nm}$ supplemental blue light resulted in an increased NAR value, whereas $470 \mathrm{~nm}$ light had no significant effect (Sirtautas et al., 2014).

\section{Conclusion}

Blue light significantly affected the biometric traits and Pn value in dill plants. At the initial period of growth only a considerable share of blue light in the spectrum inhibited the elongation growth of the plants. At later periods smaller doses of blue light also affected the elongation of the plants. Thus, we can suppose that the reaction of the dill plants to blue light depended not only on the dose but also on the stage of development of the plants. In general, blue light inhibited the elongation growth, increase in dry weight and the area of dill plants. A high share of blue light $(40-50 \%)$ also inhibited the net photosynthetic intensity.

The research showed that blue light modified the growth of dill plants and could be used as a tool for controlling plant elongation, especially at the initial growth period. 


\section{References}

Callan NW, Johnson DL, Westcott MP, Welty LE (2007). Herb and oil composition of dill (Anethum graveolens L.): Effects of crop maturity and plant density. Industrial Crops and Products 25:282-287.

Darko E, Heydarizadeh P, Schoefs B, Sabzalian MR (2014). Photosynthesis under artificial light: the shift in primary and secondary metabolism. Philosophical Transactions of the Royal Society B 369:20130243.

Dougher TAO, Bugbee B (2001). Differences in the response of wheat, soybean and lettuce to reduced blue radiation. Photochemistry and Photobiology 73(2):199-207.

Dougher TAO, Bugbee B (2004). Long term blue light effects on the histology of lettuce and soybean leaves and stems. Journal of American Society of Horticultural Science 129(4):467-472.

Fan X, Xu X, Liu X, Tang C, Wang L, Han X (2013). Effects of light intensity on the growth and leaf development of young tomato plants grown under a combination of red and blue light. Scientia Horticulturae $153(4): 50-55$.

Frązczak B (2009). Comparison of eight dill cultivars grown in containers in different light conditions. Herba Polonica 55(3):76-83.

Frązczak B, Knaflewski M, Ziombra M (2008). The height of some spice plants depending on light conditions and temperature. Electronic Journal of Polish Agricultural Universities 11(2):16.

Galmés J, Cifre J, Medrano H, Flexas J (2005). Modulation of relative growth rate and its components by water stress in Mediterranean species with different growth forms. Oecologia 145:21-31.

Hanyu H, Shoji K (2002). Acceleration of growth in spinach by short-term exposure to red and blue light at the beginning and at the end of the daily dark period. Acta Horticulturae 580:145-150.

HälväS, Craker LE, Simon JE, Charles DJ (1992a). Light levels, growth, and essential oil in dill (Anethum graveolens L.). Journal of Herbs, Spices \& Medicinal Plants 1-2:47-58.

Hälvä S, Craker LE, Simon JE, Charles DJ (1992b). Light quality, growth, and essential oil in dill (Anethum graveolens L.). Journal of Herbs, Spices \&Medicinal Plants 1-2:59-69.

Hirai T, Amaki W, Watanabe H (2006). Action of blue or red monochromatic light on stem internodal growth depends on plant species. Acta Horticulturae 711:345-349.

Hogewoning SW, Trouwborst G, Maljaars $\mathrm{H}$, Poorter $\mathrm{H}$, van-leperen W, Harbinson J (2010). Blue light dose-responses of leaf photosynthesis, morphology, and chemical composition of Cucumis sativus grown under different combinations of red and blue light. Journal of Experimental Botany 61(11):3107-3117.

Hunt R (1982). Plant Growth Curves, the functional approach to plant growth analysis. Edward Arnold, Sheffield pp 16-46.

Johkan M, Shoji K, Goto F, Hashida S, Yoshihara T (2010). Blue lightemitting diode light irradiation of seedlings improves seedling quality and growth after transplanting in red leaf lettuce. HortScience 45(12):1809-1814.

Kwack Y, Kim KK, Hwang H, Chun C (2015). Growth and quality of sprouts of six vegetables cultivated under different light intensity and quality. Horticulture Environment and Biotechnology 56(4):437-443.
Lee S-H, Tewari RK, Hahn E-J, Peak K-Y (2007). Photon flux density and light quality induce changes in growth, stomatal development, photosynthesis and transpiration of Withania somnifera (L.) Dunal. plantlets. Plant Cell Tissue and Organ Culture 90(2):141-151.

Li H, Tang C, Xu Z (2013). The effects of different light qualities on rapeseed (Brassica napus $\mathrm{L}$.) plantlet growth and morphogenesis in vitro. Scientia Horticulturae 150:117-124.

Liu X, Guo S, Xu Z, Jiao X, Takafumi T (2011). Regulation of chloroplast ultrastructure, cross-section anatomy of leaves, and morphology of stomata of cherry tomato by different light irradiations of light-emitting diodes. HortScience 46(2):217-221.

Massa GD, Kim HH, Wheeler RM, Mitchell CA (2008). Plant productivity in response to LED lighting. HortScience 43(7):19511956.

Muneer S, Kim EJ, Park JS, Lee JH (2014). Influence of green, red and blue light emitting diodes on multiprotein complex proteins and photosynthetic activity under different light intensities in lettuce leaves (Lactuca sativa L.). International Journal of Molecular Sciences 15(3):4657-4670.

Ouzounis T, Fretté X, Rosenqvist E, Ottosen CO (2014). Spectral effect of supplementary lighting on the secondary metabolites in roses, chrysanthemums, and campanulas. Journal of Plant Physiology 171:1491-1499.

Ouzounis T, Parjikolaei BR, Fretté X, Rosenqvist E, Ottosen CO (2015). Predawn and high intensity application of supplemental blue light decreases the quantum yield of PSII and enhances the amount of phenolic acids, flavonoids, and pigments in Lactuca sativa. Frontiers in PlantScience 6:19.

Ptushenko VV, Avercheva OV, Bassarskaya EM, Berkovich YuA, Erokhin AN, SmolyaninaSO,Zhigalova TV (2015). Possible reasons of a decline in growth of Chinese cabbage under a combined narrowband red and blue light in comparison with illumination by high-pressure sodium lamp. Scientia Horticulturae 194:267-277.

Sabzalian MR, Heydarizadeh P, Zahedi M, Boroomand A, Agharokh M, Sahba MR, Schoefs B (2014). High performance of vegetables, flowers, and medicinal plants in a red-blue LED incubator for indoor plant production. Agronomy for Sustainable Development 34(4):879-886.

Samuolienè G, Brazaitytė A, Duchovskis P, Viršile A, Sirtautas R, JankauskienėJ, Sakalauskienė S, Čeidaite $A$, Vaštakaitè V, Sasnauskas A (2014).Light-emitting diodes: a tool for growth and metabolism handle. In: Light Sources 2014, Proceedings of the 14th International Symposium on the Science and Technology of Lighting. Como, Italy.

Samuolienè G, Brazaitytè A, Urbonavičiūtè A, Šabajevienė G, Duchovskis P (2010). The effect of red and blue light component on the growth and development of frigo strawberries. Zemdirbyste-Agriculture 97(2):99104.

Samuolienė G, Sirtautas R, Brazaityte A, Sakalauskaitė J, Sakalauskienè S, Duchovskis P (2011). The impact of red and blue light-emitting diode illumination on radish physiological indices. Central European Journal of Biology 6(5):821-828. 
40

Sirtautas R, Virsile A, Samuoliene G, Brazaityte A, Miliauskiene J, Sakalauskiene S, Duchovskis P (2014). Growing of leaflettuce (Lactuca sativa $\mathrm{L}$.) under high-pressure sodium lamps with supplemental blue, cyan and green LEDs. Zemdirbyste-Agriculture 101(1):75-78.

Sun XD (2008). Discussion on experiment of influence factor of stomatal movement.Journal of Anhui Agriculture Sciences 36:7995-7999.

Terashima I, Fujita T, Inoue T, Chow WS, Oguchi R (2009). Green light drives leaf photosynthesis more efficiently than red light in strong white light: revisiting the enigmatic question of why leaves are green. Plant and Cell Physiology 50:684-697.

Terfa MT, Poudel MS, Roro AG, Gislerød HR, Olsen JE, Torre S (2012). Light emitting diodes with a high proportion of blue light affects external and internal quality parameters of pot roses differently than the traditional high pressure sodium lamp. Acta Horticulturae 956:635642.

Terfa MT, Solhaug KA, Gislerød HR, Olsen JE, Torre S (2013). A high proportion of blue light increases the photosynthesis capacity and leat formation rate of Rosa $\times$ hybridabut does not affect time to flower opening. Physiologia Plantarum 148(1):146-159.
Wang H, Gu M, Cui J, Shi K, Zhou Y, Yu J (2009). Effects of light quality on $\mathrm{CO}_{2}$ assimilation, chlorophyll-fluorescence quenching, expression of Calvin cycle genes and carbohydrate accumulation in Cucumis sativus. Journal of Photochemistry and Photobiology B, Biology 96:30-37.

Wang XY, Xu XM, Cui J (2015). The importance of blue light for leaf expansion, development of photosynthetic apparatus, and ultrastructure of Cucumis sativus grown under weak light. Photosynthetica 53(2):213222.

Whitelam G,Halliday K (2007).Light and plant development. Oxford UK. Wojciechowska R, Długosz-Grochowska O, Kottona A, Żupnik B (2015). Effects of LED supplemental lighting on yield and some quality parameters of lamb's lettuce grown in two winter cycles. Scientia Horticulturae 187:80-86.

Woźny A (2011). Use of light control the growth of Salvia splendes Sellow ex Roem. Et Schult. seedlings. Acta Scientiarum Polonorum Hortorum Cultus 10(4):99-106.

Yorio NC, Goins GD, Kagie HR, Wheeler RM, Sager JC (2001). Improving spinach, radish, and lettuce growth under red light-emitting diodes (LEDs) with blue light supplementation. HortScience 36:380383. 